\title{
Electrocoagulation For Oil and Grease Wastewater Treatment Using Iron Electrodes
}

\author{
Hisham K. El-Etriby ${ }^{(1)}$, Kamal H. Radwan ${ }^{(1)}$, Karim Taha ${ }^{(2)}$ \\ (1)Assoc. Prof. ,Public Works Depart., Faculty of Eng., Mansoura University. \\ (2)Civil Eng., Graduated year 2012, Mansoura University.
}

\begin{abstract}
Batch electrocoagulation (EC) experiments were carried out to evaluate the removal of COD and O\&G from wastewater using iron electrodes. The effects of operating parameters such as current intensity, initial COD concentration and contact time on COD and O\&G removal efficiency had been investigated. It was found that increasing current intensity increased COD and O\&G removal efficiency. Initial COD concentration had a little effect on removal efficiencies. Results showed that the COD removal efficiencies after 60 min. was $80.87-84.1 \%$ at current of $1.3 \mathrm{~A}, 96.1-97.9 \%$ at $1.6 \mathrm{~A}$ and after $45 \mathrm{~min}$. was $97.9-98.6 \%$ at $1.9 \mathrm{~A}$. It can be noticed that after $60 \mathrm{~min}$, for initial COD concentration of $1280 \mathrm{mg} / \mathrm{l}$ the percentage COD removal was $83.13 \%$, at 11.6 volt and 1.3 ampere, $97.5 \%$, at 14 volt and 1.6 ampere and was $98.6 \%$ at 16.4 volt and 1.9 ampere ,after $45 \mathrm{~min}$.
\end{abstract}

Key words: Electrocoagulation, Electrodes, Oil and grease and COD removal efficiency.

\section{Introduction}

The O\&G contained in the wastewater aggregate and foul the sewer system and produce unpleasant odor (2) .Environmentally problematic oily wastewaters are produced in large volumes every day. O\&G, are common pollutants found in wastes from a vast range of industries such as petroleum refineries, petrochemical, metal manufacture, machining and finishing, food processors, textile and carwash stations(3).

Main pollutant in oilfield wastewater is oil which may range between 100 and $1000 \mathrm{mg} / \mathrm{l}$ or still higher depending on the efficiency of emulsification and nature of raw oil (4). Oily wastewaters can be classification into three categories: free-floating oil, unstable oil/water emulsions, and highly stable (steady) oil/ water emulsions. Free floating oil can be readily removed by mechanical separation whilst unstable and stable oil-water $(\mathrm{O} / \mathrm{W})$ emulsions must be mechanically or chemically broken and detached gravitationally (3).

Carwash wastewaters can be harmful to humans and environment if released without treatment to surface water bodies as they contain a lot of pollutants such as detergents, oil, grease, solvent-based solutions, road grime, heavy metals, etc., that can be toxic to fish, organisms and the accumulation of these pollutant species in the aqueous bodies leads to undesirable effects on human life and on the environment (5).

The environmental requirements in the Egyptian law 93 for year 1962 and the modified law 44 for year 2000 recognize that water should be spent on sewage system does not exceed COD $1100 \mathrm{mg} / \mathrm{l}$, oil-grease 100 $\mathrm{mg} / \mathrm{l}$ and $\mathrm{pH}$ be in the range between 6 to 9.5 .

Although there were a lot of techniques available, including a variety of filters, gravity separation, air flotation, biological process, membrane bioreactor, carbon adsorption, chemical coagulation, electrocoagulation, electro flotation etc., for separation of oil-water emulsions, some of the researchers stated that there is still a lack of efficient universal technique in treating oily wastewaters $(4,6)$.

There are two kinds of coagulation: conventional coagulation and electrocoagulation . Conventional (chemical) coagulation refers to the addition of chemicals such as Alum [Al2(SO4)3 . 18H2O] to an aqueous solution to join small dispersed particles into bigger agglomerates which can be removed by some other method such as sedimentation, air floatation, or filtration $(3,7)$. Conventional coagulation involves a number of drawbacks such as the high amount of require coagulant, corrosion problems with reducing $\mathrm{pH}$ and problems with produced sludge (3). 
The rule of electrocoagulation (EC) has been popular knowledge for over 120 years with electrochemical methods first being used for water and wastewater treatment in 1887. In 1906 Dietrich invented the first electric water purifier which used aluminum electrodes whilst J.T. Harries received a patent in 1909 for wastewater treatment by electrolysis with sacrificial aluminum and iron anodes (3). The electrocoagulation of drinking water was first implemented on a large scale in the US in 1946(8).

The EC unit is environmentally friendly so that it does not produce corrosion or any pollutants. This technique has some merits when compared to conventional methods such as simple equipment, easy to apply, less retention time required and less sludge production $(5,9)$. Furthermore, Electrocoagulation is efficient in removing suspended solids as well as O\&G. Many investigators found that it removes metals, colloidal solids, particles containing arsenic, dyes, paper mills, breaking oil emulsions in water, phosphate, boron and bacteria, viruses and cysts $(9 \rightarrow 11)$.

The nature of the electrode material is a main issue in electrochemical treatment and the appropriate selection of electrode material is very essential. The most popular electrode materials used for electrocoagulation technique are aluminum and iron because they are cheap, readily available and proven effective since their dissolution in aerated media produce trivalent species (12).

In the literature it was found that the iron electrode was more effective than aluminum $(2,13)$. On the other hand, Rupesh et al. said that oil removal efficiency was $90 \%$ at $4.72 \mathrm{pH}$ within $30 \mathrm{~min}$ treatment time for $50 \mathrm{mg} / \mathrm{l}$ concentration of oil and $94.44 \%$ of oil removed in $30 \mathrm{~min}$ at $4 \mathrm{mg} / \mathrm{l}$ of salinity using Aluminum electrode (4). In the second place, Fouad treated oil-water emulsions ,In his work the initial O\&G concentrations investigated were 200, 300 and 400 ppm, pH values used were 3, 5, 7, 9 and 11(11). Maha et al., treated oil tanning effluent and proved that iron $(\mathrm{Fe})$ and aluminum $(\mathrm{Al})$ electrodes were considered as sacrificial electrodes in different combinations. They found that under best operating conditions such as $20 \mathrm{~mA} / \mathrm{cm}^{2}$ current density, $5 \%$ effluent concentration, $1.0 \mathrm{~g} / \mathrm{l} \mathrm{NaCl}$ concentration and $\mathrm{Fe} / \mathrm{Fe}$ electrodes, \% COD removal, energy consumption and operating cost were $89.65 \%, 1.279 \mathrm{~kW} \mathrm{~h} / \mathrm{m} 3$ and $6.28 \mathrm{US} \$ / \mathrm{m} 3$, respectively (15) .

This paper is primarily aimed at development the technology of $O \& G$ removal by electrocoagulation. In the present study, the effect of numerous operating conditions such as initial COD concentration, current intensity, and contact time on the removal efficiency of COD have explored and discussed to identify the optimum operational conditions and low cost.

\section{Theory of Electrocoagulation}

As shown in Fig. 1, iron is usually used as electrodes and upon the application of a direct current their cations are produced by dissolution of sacrificial anodes. The metal ions produced are hydrolyzed in the electrochemical cell to create metal hydroxide ions according to anodic and solution reactions and the solubility of the metal hydroxide complexes formed depends on $\mathrm{pH}$ and ionic power. Insoluble flocs are produced at $\mathrm{pH}$ range between 6.0 and 7.0. Positive metal species react with negatively charged particles in the water to form destabilized colloids and then flocs. The in situ generation of coagulants means that electrocoagulation processes do not require the addition of any chemicals. The gases generated at the cathode during the electrolysis of water and metal dissolution according to cathodic reaction permit the resulting flocs to float and it may be removed by any skimming technique $(4,5,7,9,16,17)$.

The oxidation - reduction reactions involved in the electrochemical cell are as follow:

Anodic (oxidation) reactions:

$F e_{(s)} \rightarrow F e_{(a q)}^{+2}+2 e^{-}$

$\mathrm{Fe}_{(a q)}^{+2}+2 \mathrm{OH}_{(a q)}^{-} \rightarrow \mathrm{Fe}(\mathrm{OH})_{2(s)}$

Cathodic (reduction) reactions:

$2 \mathrm{H}_{2} \mathrm{O}+2 e^{-} \rightarrow \mathrm{H}_{2}(\mathrm{~g})+2 \mathrm{OH}_{(a q)}^{-}$

In the solution:

$\mathrm{Fe}_{(a q)}^{+3}+\mathrm{H}_{2} \mathrm{O} \rightarrow \mathrm{Fe}(\mathrm{OH})_{(a q)}^{+2}+2 H_{(a q)}^{+}$ 


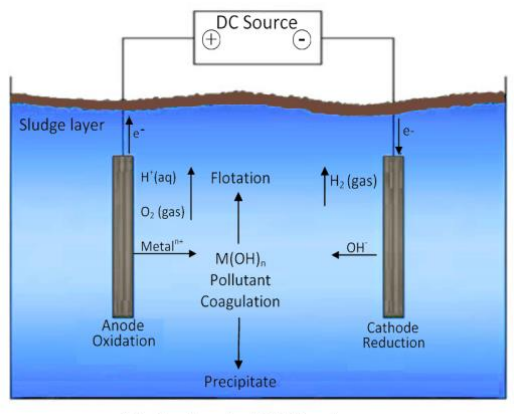

Electrochemical Cell Reactor

Fig. 1

The quantity of electrode material dissolved or consumed during the electrocoagulation process depended heavily on the current intensity as explained by the Faraday' s law as follow $(5,7,8)$.

$\mathrm{m}=\frac{M I t}{n F v o l}$

where : $\mathrm{m}$ is the mass of dissolved metal $(\mathrm{gm} / \mathrm{L}) ; \mathrm{M}$ is the molecular weight $(\mathrm{g} / \mathrm{mol})(\mathrm{MFe}=56 \mathrm{~g} / \mathrm{mol})$; I is the current intensity (Ampere); $\mathrm{t}$ is the contact time (second); $\mathrm{n}$ is the number of electrons involved in the oxidation reduction reaction $(\mathrm{nFe}=2)$; and $\mathrm{F}$ is the Faraday' s constant $(96,485 \mathrm{C} / \mathrm{mol})$ and vol is the sample volume (liter).

\section{Materials and methods}

\subsection{Experimental set-up}

Experiments were implemented in a batch electrochemical rectangular glass cell shown in Fig. 2 that had the following dimensions: $21 \mathrm{~cm}$ long, $15 \mathrm{~cm}$ wide, and $30 \mathrm{~cm}$ height. The total volume of 6 liters of wastewater was treated in the electrochemical cell with $20 \mathrm{~cm}$ wetted depth and $10 \mathrm{~cm}$ free board. Six parallel plate electrodes made of rectangular metal sheets with dimensions of $30 \mathrm{~cm}$ height, $10 \mathrm{~cm}$ wide, and $1 \mathrm{~mm}$ thickness were used. Three electrodes of them were connected parallel as anodes and the other three connected as cathodes. These electrodes connected in a monopolar mode separated by a space of $3 \mathrm{~cm}$ and an immersed height of $16 \mathrm{~cm}$ (because if the spacing between electrodes $<10 \mathrm{~mm}$ it impeded movement of liquid and hindering removal efficiency) (18). The electrode gap was kept constant in all experiments. The immersed area of one electrode was $160 \mathrm{~cm}^{2}$. The metal electrodes were dropped to the wastewater sample and connected to digital multi meter, KEW SNAP model-2007, for measurement the current and the potential between the electrodes. The D.C. power supply output had three different current conditions: $1.3 \mathrm{~A}, 1.6 \mathrm{~A}$ and 1.9 A with the volts of $11.6 \mathrm{~V}, 14 \mathrm{~V}$ and $16.4 \mathrm{~V}$, respectively.

\subsection{Synthetic oil-water emulsions:}

Emulsions were set by adding dosages of dirty vehicles motor oil (Mobil Oil) to 1 liter of tap water and violently mixed for $3 \mathrm{~min}$. The mixture showed a uniform white color.

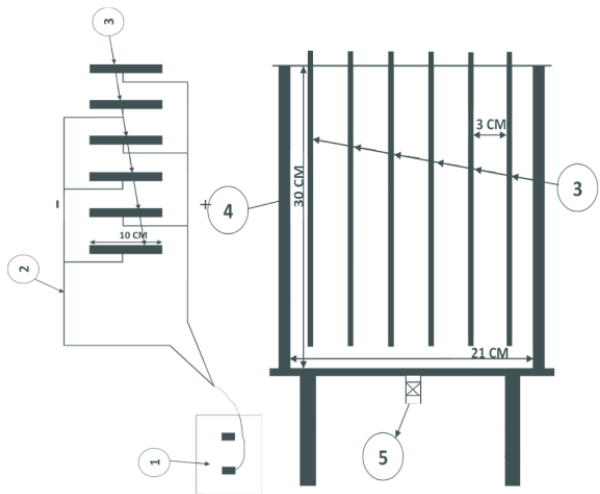

(Plan) (Elevation) 
Fig. 2.A schematic diagram: (1) DC power supply, (2) Anode and cathode connections, (3) six electrodes of iron), (4) electrocoagulation cell, and (5) drainage valve.

After preparation the emulsion, it was left for $30 \mathrm{~min}$ to observe its stability. The emulsion was prepared by initial oil and grease concentrations of $400 \mathrm{mg} / \mathrm{l}, 550 \mathrm{mg} / \mathrm{l}$ and $700 \mathrm{mg} / \mathrm{l}$ that gave initial COD $1100 \mathrm{mg} / \mathrm{l}, 1280$ $\mathrm{mg} / \mathrm{l}$ and $1500 \mathrm{mg} / \mathrm{l}$ respectively. Therefore COD value was taken as a measure of O\&G. The initial $\mathrm{pH}$ ranged from 5.9 to 8.2 .

\subsection{Experimental method}

First EC-cell was filled with the synthetic -water emulsion. Electrodes were submerged and then the current was passed by the regulated DC power supply. The reaction was timed, beginning when the D.C. power supply was switched on. The electrodes polarity was changed at time intervals of $15 \mathrm{~min}$. Samples of $5 \mathrm{ml}$ of oil-water emulsion were withdrawn from the depth of $5 \mathrm{~cm}$ below the free surface of oil-water emulsion at regular time intervals of $15 \mathrm{~min}$. The effect of the electrochemical treatment was determined by measuring COD at the regular time intervals of $15 \mathrm{~min}$. After each run the electrodes were cleaned and rinsed with $\mathrm{HCl}$ (10\%concentration) to remove the oxides formed at the anode surface and then dried.

Anodic dissolution was determined by measuring weight of sacrificial anode before and after experiments.

\subsection{Analytical measurement}

The experimental parameters measured were COD, O\&G concentration, conductivity, TDS and pH. Analysis was carried out by the standard method for the examination of water and wastewater (22nd edition, 2012) (1).

The COD was measured by the closed reflux, colorimetric method and $\mathrm{O} \& \mathrm{G}$ was measured by hexane extractable method according to standard methods (1). The removal efficiency was determined as $(\mathrm{C} 0-\mathrm{C}) / \mathrm{C} 0$.

In order to accomplish the aims of this study three sets of runs were planed. Each set of them contained three experiments with different calculated $O \& G$ concentration $(400,550,700 \mathrm{mg} / \mathrm{lit}$.).

\section{Result and discussion}

\subsection{Effect of electrode material \& current density \\ 4.1.1. Iron electrodes $\quad(\mathrm{Fe} / \mathrm{Fe}$ system)}

Results of the second 3 sets of runs with Fe electrodes were depicted in figures (1 -3). From it can be noticed that after $60 \mathrm{~min}$, for initial COD concentration of $1280 \mathrm{mg} / \mathrm{l}$ the percentage COD removal was $83.13 \%$, at 11.6 volt and 1.3 ampere, $97.5 \%$, at 14 volt and 1.6 ampere and was $98.6 \%$ at 16.4 volt and 1.9 ampere ,after $45 \mathrm{~min}$. As shown in figurse ( 1 -3), the COD removal efficiencies after $60 \mathrm{~min}$. was $80.87-84.1 \%$ at current of $1.3 \mathrm{~A}, 96.1-97.9 \%$ at $1.6 \mathrm{~A}$ and after $45 \mathrm{~min}$. was $97.9-98.6 \%$ at $1.9 \mathrm{~A}$.

. It is commonly noted that $\mathrm{pH}$ increases during an electrochemical process because the process leads to the formation of metal hydroxide according to previous equations (19).

$\mathrm{pH}$ increasing was in the range of 3.0 to 4.5 at using iron electrodes.

The COD removal efficiency increased from $80.87 \%$ to $96.1 \%$ by increasing the current voltage from 11.6 volt to 14 volt. When the applied current voltage was increased from 14 volt to 16.4 volt, there was not noticeable change in COD removal efficiency as seen in figures $(1 \rightarrow 3)$.

It can be showed from figure (1) that in the low range of current intensities, as the quantity of dissolved metal was small, the solid particles of metal hydroxide formed have of this fact, small dimension and did not permit to an efficient adsorption of the emulsions. These small particles of metal hydroxide, which remain in suspension, lead to no increase in COD removal efficiency (12).

Based on Faraday's law, increasing applied voltage (or current intensity) resulted in an increasing amount of metal hydroxide flocs for the removal of colloidal particles (17). 
It was also recognized that the rate of bubble-generation increased and the bubble size decreased with increasing current intensity; both of these facts were beneficial in terms of high pollutant removal efficiency by $\mathrm{H}_{2}$ flotation $(14,16)$.

The difference of conductivity between the beginning and the end of experiments increased with increasing current intensity.

Initial COD concentration had a low effect on COD removal efficiency.

\subsection{Effect of contact time}

The time range from 0 to $60 \mathrm{~min}$ was studied to show how time affected the removal efficiencies. As the time of electrolysis increased comparable changes in the removal efficiency of COD was observed.

COD removal efficiency increased with increasing contact time. According to the Faraday's law, the amount of iron released to the EC system using Fe was affected by the residence time which leads to an increase in $\mathrm{Fe}$ ions freed to the system.

at using iron electrodes it is shown in figures (1-3) That COD removal efficiency increased fastly at first 30 min and increased slowly at last $30 \mathrm{~min}$.

\subsection{Sludge production}

The effluent with iron electrodes appeared brown first, and then turned black and turbid. About two thirds of the sludge floated on the top and came out from a sludge outlet, while the other third was generated after sedimentation (2).

Volume of sludge from each patch increased with increasing initial concentration and current intensity. Minimum and maximum sludge volume $220.5 \mathrm{~cm}^{3}$ and $472.5 \mathrm{~cm}^{3}$ for iron electrodes.

\section{Total cost}

One of the most important parameters that greatly affect the application of any technique of wastewater treatment is the cost.

The electrical energy consumption increased with increasing current. Since the current is a main variable in controlling the performance of the electrocoagulation, it is preferable to decrease cell voltage rather than decrease current to minimize the energy consumption (4). Operating time is the significant performance parameter in the electrocoagulation process as higher operating time results in higher energy requirement (15). Electrical energy Consumption was calculated using the following equation:

$$
\mathrm{E}=\frac{\mathrm{VIt}}{\left(\mathrm{COD}_{\mathrm{i}-} \mathrm{COD}_{\mathrm{f}}\right) \mathrm{vol}}
$$

Where $\mathrm{E}$ is the energy consumption ( $\mathrm{kwh} / \mathrm{g} \mathrm{COD}) ; \mathrm{V}$ is the current voltage (volt); I is the current intensity (ampere); $\mathrm{t}$ is the contact time (hour); CODi , CODf is initial and final chemical oxygen demand (mg/l) respectively; and vol is the sample volume (liter).

Total Cost $\left(\mathrm{LE} / \mathrm{g}\right.$ COD removal $\left./ \mathrm{m}^{3}\right)=\mathrm{E}(\mathrm{kwh} / \mathrm{g}$ COD $) \times$ Price $(\mathrm{LE} / \mathrm{kwh})+\mathrm{m}\left(\mathrm{kg} / \mathrm{m}^{3}\right) \times$ metal Price $(\mathrm{LE} / \mathrm{kg})$

Where the price of kwh of electricity equals $0.25 \mathrm{LE}$; Price of $\mathrm{kg}$ Iron equals $6.85 \mathrm{LE}$

Total Cost of treatment shown in table 1 


\section{Conclusion}

1- The results of this study showed that electrocoagulation could be applied in the treatment of oily wastewater.

2- At using $(\mathrm{Fe} / \mathrm{Fe})$ system the COD removal efficiency after $45 \mathrm{~min}$. was $97.9-98.6 \%$ at current intensity of 1.9 A.

3- The current intensity is an important operating factor influencing the performance of electrocoagulation process and initial COD concentration has a little effect.

\section{References}

1-APHA (2012) standard methods for the examination of water and wastewater (22nd edition ) American Public Health Association, Washington, D.C .

2 -Xueming Chen, Guohua Chen *, Po Lock Yue. (1999), "Separation of pollutants from restaurant wastewater by electrocoagulation." Separation and Purification Technology 19 (2000) 65-76.

3 -M. Karhu , V. Kuokkanen, T. Kuokkanen , J. Ramo .(2012), "Bench scale electrocoagulation studies of bio oil-in-water and synthetic oil-in-water emulsions." Separation and Purification Technology 96 (2012) 296-305.

4 -Rupesh M. Bande, B. Prasad, I.M. Mishra, Kailas L. Wasewar . (2007), "Oil field effluent water treatment for safe disposal by electroflotation." Chemical Engineering Journal 137 (2008) 503-509.

5 -Marco Panizza *, GiacomoCerisola .(2009), "Applicability of electrochemical methods to carwash wastewaters for reuse." Journal of Electroanalytical Chemistry 638 (2010) 236-240.

6-Bahadır K. Körbahti $\square$, KahramanArtut .(2010), "Electrochemical oil/water demulsification and purification of bilge water using Pt/Ir electrodes." Desalination 258 (2010) 219-228.

7-Muftah H. El-Naas*, Sulaiman Al-Zuhair, Amal Al-Lobaney, SouzanMakhlouf .(2009), "Assessment of electrocoagulation for the treatment of petroleum refinery wastewater." Journal of Environmental Management 91 (2009) 180-185.

8-Ayhan $\mathrm{S}_{\text {s }}$ engil ,Mahmut "ozacar.(2006), "Treatment of dairy wastewaters by electrocoagulation using mild steel electrodes." Journal of Hazardous Materials B137 (2006) 1197-1205.

9-Serkan Bayar ,YalçınŞevkiYıldız, AlperErdemYılmaz, Şahsetİrdemez .(2011), "The effect of stirring speed and current density on removal efficiency of poultry Slaughterhouse wastewater by electrocoagulation method." Desalination 280 (2011) 103-107.

10-Muftah H. El-Naas ,Manal Abu Alhaija, Sulaiman Al-Zuhair .(2013), "Evaluation of a three-step process for the treatment of petroleum refinery wastewater." Journal of Environmental Chemical Engineering 2 (2014) 5662.

11-Ivonne Linares-Hernández, Carlos Barrera-Díaz,* , Bryan Bilyeu, Pablo Juárez-GarcíaRojas, Eduardo Campos-Medinac.(2009), "A combined electrocoagulation-electro oxidation treatment for industrial wastewater." Journal of Hazardous Materials 175 (2010) 688-694 .

12-K. Bensadok ， N. El Hanafi, F. Lapicque . (2011), "Electrochemical treatment of dairy effluent using combined Al and Ti/Pt electrodes system." Desalination 280 (2011) 244-251.

13-Alexandre Andrade Cerqueira and Monica Regina da Costa Marques"Electrolytic Treatment of Wastewater in the Oil Industry. ".

14-Y.O. Fouad .(2013), "Separation of cottonseed oil from oil-water emulsions using electrocoagulation technique." Alexandria Engineering Journal (2013) . 
15-P. Maha Lakshmi, P. Sivashanmugam. (2013), "Treatment of oil tanning effluent by electrocoagulation: Influence of ultrasound and hybrid electrode on COD removal." Separation and Purification Technology 116 (2013) 378-384.

16-Umran TezcanUn , A. SavasKoparal, UlkerBakirOgutveren.(2007),"Electrocoagulation of vegetable oil refinery wastewater using aluminum electrodes." Journal of Environmental Management 90 (2009) 428-433.

17-Orathai Chavalparit1, ManeeratOngwandee .(2009), "Optimizing electrocoagulation process for the treatment of biodiesel wastewater using response surface methodology." Journal of Environmental Sciences 21(2009) 1491-1496.

18-Deepak Sharma.(2014), "Treatment of dairy waste water by electro coagulation using aluminum electrodes and settling, filtration studies." International Journal of ChemTech Research Vol.6, No.1, pp 591-599, Jan-March 2014.

19-Chantaraporn Phalakornkule, JuntipaMangmeemak, KanitaIntrachod, BoonyaritNuntakumjorn .(2010),

"Pretreatment of palm oil mill effluent by electrocoagulation and coagulation." Science Asia 36 (2010): 142-149 
Table 1 Total Cost of treatment of cubic meter for each gm COD Removal using Iron electrodes.

\begin{tabular}{|c|c|c|}
\hline \multirow{2}{*}{ Volt and Ampere } & Initial COD concentration (mg/L.) & Total cost(LE) \\
\hline \multirow{2}{*}{$\begin{array}{c}11.6 \text { volt } \\
\text { Ampere } \\
\text { (after } 1 \mathrm{hr})\end{array}$} & 1500 & 3.73 \\
\cline { 2 - 3 } & 1280 & 3.809 \\
\hline \multirow{2}{*}{$\begin{array}{c}14 \text { volt } \\
\text { Ampere } \\
(\text { after } 1 \mathrm{hr})\end{array}$} & 1100 & 3.89 \\
\cline { 2 - 3 } & 1500 & 4.6 \\
\hline \multirow{2}{*}{$\begin{array}{c}16.4 \text { volt } \\
(\text { After } 45 \text { min })\end{array}$} & 1280 & 4.72 \\
\cline { 2 - 3 } & 1100 & 4.187 \\
\cline { 2 - 3 } & 1500 & 4.29 \\
\hline
\end{tabular}

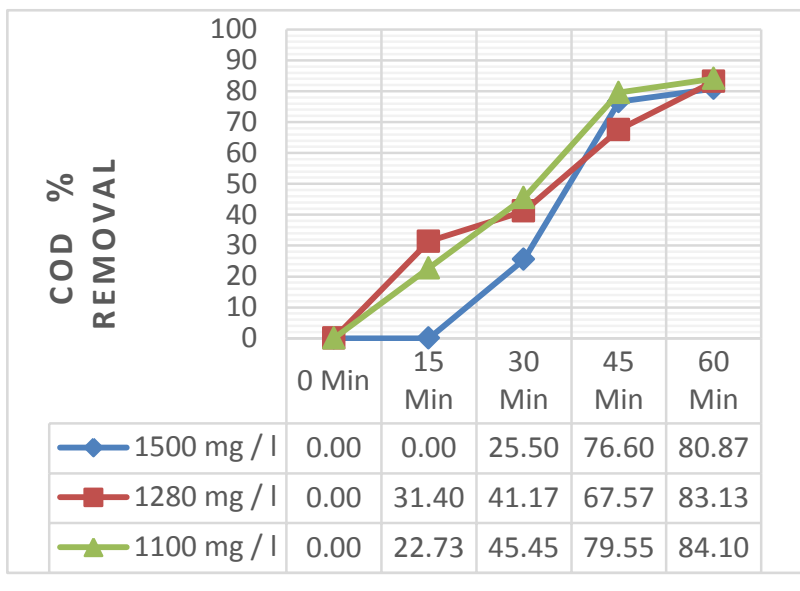

Fig. 1 COD removal with Fe electrodes at 11.6 volt and 1.3 ampere.

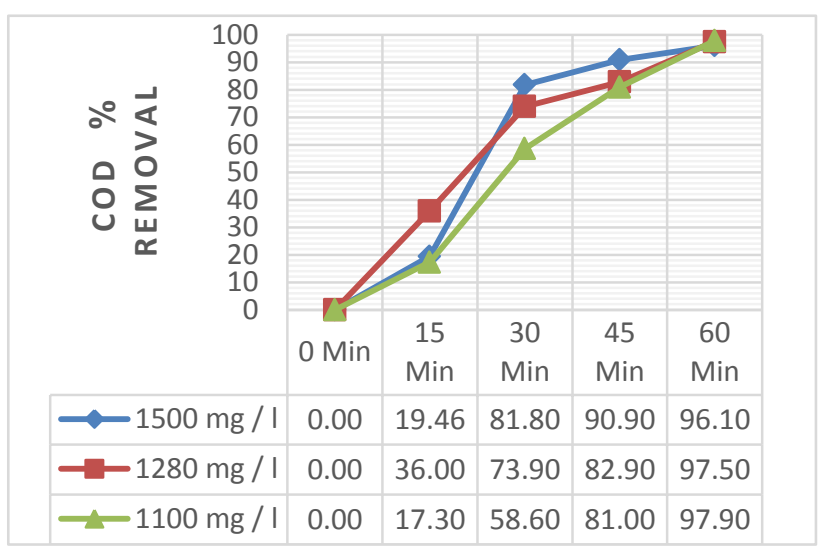

Fig. 2 COD removal with Fe electrodes at 14 volt and 1.6 ampere.

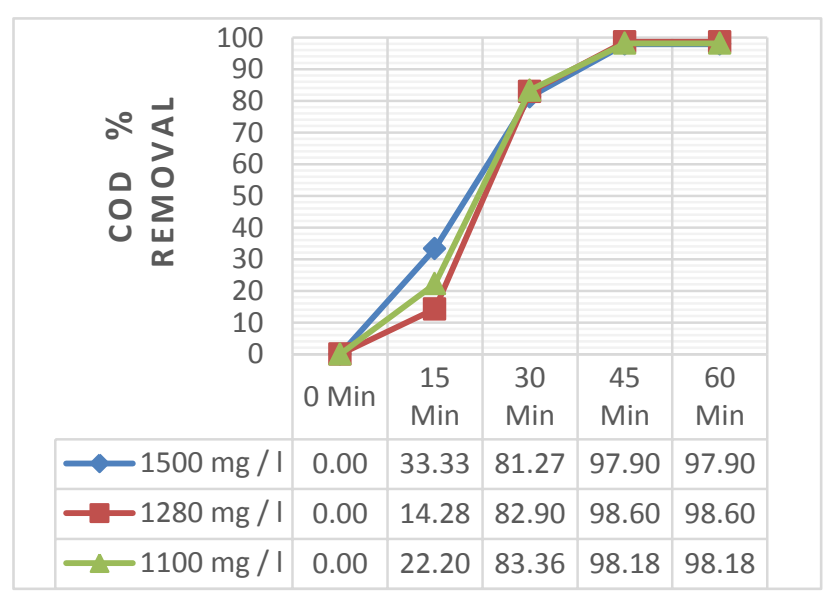

Fig. 3 COD removal with Fe electrodes at 16.4 volt and 1.9 ampere. 